Article

\title{
Comparison of Different Enhanced Coagulation Methods for Azo Dye Removal from Wastewater
}

\author{
Xinhao Luo ${ }^{1,2} \odot$, Chen Liang ${ }^{1,2}$ and Yongyou $\mathrm{Hu}^{1,2, *}$ \\ 1 School of Environment and Energy, South China University of Technology, Guangzhou Higher Education \\ Mega Centre, Guangzhou 510006, China \\ 2 The Key Lab of Pollution Control and Ecosystem Restoration in Industry Clusters, Ministry of Education, \\ South China University of Technology, Guangzhou Higher Education Mega Centre, \\ Guangzhou 510006, China \\ * Correspondence: ppyyhu@scut.edu.cn
}

Received: 20 July 2019; Accepted: 27 August 2019; Published: 30 August 2019

check for updates

\begin{abstract}
Printing and dyeing wastewater (PDW) is considered to be one of the most difficult industrial wastewaters to treat because of its large quantities, high $\mathrm{pH}$ values, and high color and toxicity, which may endanger the lives of animals and humans. In this study, we assessed the chemical decolorization process of Congo Red in azo dyes using response surface methodology (RSM), and the effect of different enhanced coagulation pretreatment processes (ECPPs) on the microbial community structure of PDW using high-throughput sequencing technology. We concluded that, based on the initial concentration and $\mathrm{pH}$ of Congo Red, different decolorants can be selected for decolorization reactions. In addition, it was found that the microbial community of the wastewater after three different ECPP treatments was similar to the raw wastewater and the oxidation ditch wastewater from a treatment plant. We also found that the ECPPs with polymeric iron sulfate had the smallest effect on the microbial community. In practical applications, these findings provide a reference for an established link between the physicochemical and biochemical treatment of PDW.
\end{abstract}

Keywords: azo dye; decolorization; coagulation and flocculation; bacterial community; response surface methodology (RSM)

\section{Highlights}

Parameters of enhanced coagulation pretreatment processes (ECPPs) were optimized by response surface methodology (RSM).

Different chemical decolorization processes can be selected according to the initial $\mathrm{pH}$ and concentration of Congo Red.

A relationship was developed between the physicochemical and biochemical treatment of printing and dyeing wastewater (PDW).

\section{Introduction}

Coloring agents and dyes are widely used in the modern textile industry, as well as other manufacturing industries. Any dyes left in the effluent after treatment (printing and dyeing wastewater; PDW) are discharged into the water environment, and can cause surface water pollution $[1,2]$. The coloring material usually only absorbs about $80 \%$ of the dye [3]. PDW is toxic and could endanger human and animal life. It is also very difficult to remove from industrial wastewater; thus, it is widely concerning for society [4].

Mass et al. (2005) estimated that $2.8 \times 10^{5}$ tons of textile dyes are discharged into the water with textile industry wastewater every year around the world. Among them, azo dyes account for about 
half of all synthetic dyes [5]. Azo reactive dyes have nitrogen-nitrogen double bonds [6], and some azo dyes and their decomposition products are toxic and may mutate living organisms [7]. Azo dyes also have poor biodegradability because they possess electron-withdrawing groups in their structures, which generate electron-deficient dye molecules [8].

PDW has a high $\mathrm{pH}$ value, color content, water temperature, and toxicity, as well as other characteristics, and a lot of wastewater is created in the printing and dye process; thus, it is difficult for certain technologies to treat it. Physical, chemical, and biological treatment technologies should, therefore, be combined for its treatment $[4,9,10]$. Among them, coagulation-flocculation is one of the physicochemical treatment methods currently used for PDW [11]. It is often used in the pretreatment process of PDW, and can effectively remove most of the dyes, thus reducing the load for the subsequent biochemical treatment facilities $[12,13]$. Coagulation technology adds high-dose coagulants that maintain a particular $\mathrm{pH}$ value to sewage in order to improve the removal of pollutants using conventional treatments [14]. Factors affecting the coagulation effect include water temperature, $\mathrm{pH}$, dosage, hydraulic conditions, and raw water quality [15]. In actual wastewater, it is often used to treat wastewater with varying water quality by adjusting $\mathrm{pH}$ and dosage.

There are a large number of microorganisms indigenous to the wastewater-regulating pools of printing and dyeing industrial parks. Different enhanced coagulation pretreatment processes (ECPPs) have different effects on these microorganisms $[12,16]$. High-throughput sequencing technology can be used to analyze any changes in microbial community composition in PDW from industrial parks before and after ECPPs, which can then be used to compare microbial community composition in any subsequent biological treatment facilities.

In this study, we wanted to test the capability of ECPPs for PDW treatment. Firstly, we studied azo dye removal efficiency using different ECPP methods and simulation tests. Next, we explored the relationship between using different ECPPs and the associated microbial community changes in industrial park PDW. These results provide a reference for further research studying the relationship between physicochemical and biological PDW treatment methods.

\section{Materials and Methods}

\subsection{Water Samples}

Based on our experimental design, water samples were divided into two categories. The first was simulated wastewater. Congo Red in azo dyes was selected as the target pollutant for our wastewater simulations. The second category was actual wastewater, and these samples were taken from the regulating tank of the Datang Printing and Dyeing Industrial Park wastewater treatment plant in Foshan city, Guangdong province, China. The actual characteristics of the wastewater are shown in Table A4 (Appendix A).

\subsection{Chemicals}

The following chemical agents were selected to use in the coagulation process: calcium hydroxide $\left(\mathrm{Ca}(\mathrm{OH})_{2}\right.$, analytically pure, used as a neutralizing base, no synergistic effect of complexation and flocculation in a parallel experiment with $\mathrm{NaOH})$, ferrous sulfate $\left(\mathrm{FeSO}_{4} \cdot 7 \mathrm{H}_{2} \mathrm{O}\right.$, analytically pure, used as a coagulant), aluminum sulfate $\left(\mathrm{Al}_{2}\left(\mathrm{SO}_{4}\right)_{3} \cdot 18 \mathrm{H}_{2} \mathrm{O}\right.$, analytically pure, used as a coagulant), polymeric iron sulfate $\left(\left[\mathrm{Fe}_{2}(\mathrm{OH})_{\mathrm{n}}\left(\mathrm{SO}_{4}\right)_{3}-\mathrm{n} / 2\right]_{\mathrm{m}}(\right.$ where $\mathrm{n}<2, \mathrm{~m}=\mathrm{f}(\mathrm{n}))$, analytically pure, used as a coagulant), and non-ionic polyacrylamide (analytically pure, used as a flocculant).

\subsection{Jar Tests of Simulated Wastewater}

The chemical agents were tested using the $1000-\mathrm{mL}$ raw water samples and a programmable Jar test instrument using the following standard procedure: rapid stirring at $200 \mathrm{rpm}$ for $2 \mathrm{~min}$ during neutralization, stirring at $200 \mathrm{rpm}$ for $5 \mathrm{~min}$ after adding coagulant, stirring at $100 \mathrm{rpm}$ for $10 \mathrm{~min}$ after adding flocculant, and then settling for $30 \mathrm{~min}$. 


\subsection{ECPPs of Actual Wastewater}

The chemical agents were pretreated using the following procedure: $\mathrm{Ca}(\mathrm{OH})_{2}$ was added to 1000 $\mathrm{mL}$ of actual wastewater until a pH of 9.0 was achieved, and then stirred at $200 \mathrm{rpm}$ for $5 \mathrm{~min}$; ferrous sulfate was added with a dosage of $150 \mathrm{mg} / \mathrm{L}$, and then stirred at $200 \mathrm{rpm}$ for $5 \mathrm{~min}$, before stirring at $100 \mathrm{rpm}$ for $10 \mathrm{~min}$ after adding flocculant, and then settling for $30 \mathrm{~min}$; the supernatant was collected and labeled sample L1.

The same procedure was used for the coagulants aluminum sulfate and polymeric iron sulfate, with the collected supernatant samples labeled as L2 and L3, respectively.

\subsection{Optimal Design of Response Surface Methodology (RSM)}

In this study, we used three surface response experiments at indoor temperature. In the first experiment, ferrous sulfate was used as the decolorizing agent; in the second experiment, aluminum sulfate was used as the decolorizing agent; in the third experiment, polymeric iron sulfate was used as the decolorizing agent. On the basis of single-factor experiments, the numerical ranges of the influencing factors of all three experiments were determined.

The first experiment was designed with three factors at three levels $(+1,-1,0)$ at $\mathrm{pH} 6,8$, and 10, with initial Congo Red concentrations of $50 \mathrm{mg} / \mathrm{L}, 100 \mathrm{mg} / \mathrm{L}$, and $150 \mathrm{mg} / \mathrm{L}$, and chemical doses of $80 \mathrm{mg} / \mathrm{L}, 140 \mathrm{mg} / \mathrm{L}, 200 \mathrm{mg} / \mathrm{L}$. Seventeen experiments were designed using Design-Expert (version 8.06) software design (Table A1, Appendix A). The second-order polynomial equation was based on Shao et al. (2018) and Su et al. (2016) [10,17].

The second experiment was designed with three factors at three levels $(+1,-1,0)$ at $\mathrm{pH} 5,7$, and 9, with initial Congo Red concentrations of $100 \mathrm{mg} / \mathrm{L}, 200 \mathrm{mg} / \mathrm{L}$, and $300 \mathrm{mg} / \mathrm{L}$, and chemical doses of $20 \mathrm{mg} / \mathrm{L}, 50 \mathrm{mg} / \mathrm{L}, 80 \mathrm{mg} / \mathrm{L}$. Seventeen experiments were designed using Design-Expert (version 8.06) software design (Table A2, Appendix A). The second-order polynomial equation was based on Shao et al. (2018) and Su et al. (2016) [10,17].

The third experiment was designed with three factors at three levels $(+1,-1,0)$ at $\mathrm{pH} 5,7$, and 9, with initial Congo Red concentrations of $50 \mathrm{mg} / \mathrm{L}, 100 \mathrm{mg} / \mathrm{L}$, and $150 \mathrm{mg} / \mathrm{L}$, and chemical doses of $50 \mathrm{mg} / \mathrm{L}, 100 \mathrm{mg} / \mathrm{L}, 150 \mathrm{mg} / \mathrm{L}$. Seventeen experiments were designed using Design-Expert (version 8.06) software design (Table A3, Appendix A). The second-order polynomial equation was based on Shao et al. (2018) and Su et al. (2016) [10,17].

\subsection{Analytical Methods of Chemical Indexes}

The $\mathrm{pH}$ was measured directly using a digital $\mathrm{pH}$ meter (PHS-3C, China), and Congo Red concentrations were measured by a method with a wavelength equal to $496 \mathrm{~nm}$ using an $\mathrm{HACH}$ instrument (DR5000, USA).

\subsection{Sequencing Analysis of Microorganisms}

The microbial community of raw wastewater, water samples pretreated by enhanced coagulation, and water samples from the oxidation ditch of the wastewater treatment plant were analyzed. Two-milliliter samples were extracted from each water sample and sent to Biomarker Technologies CO., LTD (Beijing, China) for high-throughput sequencing. The microbial diversity calculations were based on the Illumina Hiseq sequencing platform, and a small fragment library was constructed using a paired-end sequencing method. Primers used were as follows: 338 forward (F): 5'-ACTCCTACGGGAGGCAGCA-3'; 806 reverse (R): 5'-GGACTACHVGGGTWTCTAAT-3' . 


\section{Results and Discussion}

\subsection{Box-Behnken Design for Optimizing Factors in the First Experiment}

RSM with a Box-Behnken design was used to analyze the interaction between the basic variables affecting the decolorization removal ratio of Congo Red by ferrous sulfate. These included the $\mathrm{pH}$ of the reaction, the initial Congo Red concentration, and the dosage of ferrous sulfate. The interaction between two independent variables was determined using response surface curves and contours. The quadratic polynomial equation constructed by the coding factor was as follows:

$$
R_{C R}=69.44+13.41 A+11.94 B-8.38 C-7.28 A B+5.85 A C-1.15 B C+7.14 A^{2}-0.26 B^{2}+1.82 C^{2} \text {, }
$$

where $R_{C R}$ is the decolorization ratio of Congo Red, and $A, B$, and $C$ represent the $\mathrm{pH}$ of the reaction, the dosage of ferrous sulfate, and the initial Congo Red concentration, respectively.

Table 1 shows the regression coefficient, standard error, F-value, and $p$-value. The model F-value of 43.85 implies that the model was significant. There was only a $0.01 \%$ chance that a value that large could be caused by noise. Table 1 shows that the linear coefficient $(p<0.0001)$ of $\mathrm{pH}$ of the reaction, the linear coefficient $(p<0.0001)$ of dosage of ferrous sulfate, and the linear coefficient $(p<0.0001)$ of initial Congo Red concentration $(p=0.0001)$ were all vitally significant and had the largest effect on the decolorization ratio of Congo Red. Furthermore, the linear coefficient of the $\mathrm{pH}$ of the reaction with ferrous sulfate dosage $(p=0.0021)$, the linear coefficient of the $\mathrm{pH}$ of the reaction with initial Congo Red concentration ( $p=0.0067)$, and the quadratic coefficient of the $\mathrm{pH}$ of the reaction $(p=0.0020)$ were also all significant (Table 1$)$.

Table 1. Regression analysis of least square fitting in the first experiment.

\begin{tabular}{ccccc}
\hline Source & $\begin{array}{c}\text { Regression } \\
\text { Coefficient }\end{array}$ & Standard Error & F-Value & $p$-Value Prob $>$ F \\
\hline Model & - & - & 43.85 & $<0.0001$ \\
A-pH of the reaction & 13.41 & 1.09 & 152.27 & $<0.0001$ \\
B-dosage of ferrous sulfate & 11.94 & 1.09 & 120.62 & $<0.0001$ \\
C-initial Congo Red concentration & -8.38 & 1.09 & 59.37 & 0.0001 \\
AB & -7.28 & 1.54 & 22.40 & 0.0021 \\
AC & 5.85 & 1.54 & 14.48 & 0.0067 \\
BC & -1.15 & 1.54 & 0.56 & 0.4788 \\
$\mathrm{~A}^{2}$ & 7.14 & 1.50 & 22.73 & 0.0020 \\
$\mathrm{~B}^{2}$ & -0.26 & 1.50 & 0.030 & 0.8684 \\
$\mathrm{C}^{2}$ & 1.82 & 1.50 & 1.47 & 0.2644 \\
\hline
\end{tabular}

$R^{2}=0.9826$; adjusted $R^{2}=0.9602$; coefficient of variation $=4.18 \%$. " $0.01<p$-value $<0.05$ " and " $p$-value $>0.1$ " in model terms with "Prob $>F^{\prime}$ " were considered to be significant and insignificant, respectively (Su et al., 2016; Shao et al., 2018).

Figure 1 shows the three-dimensional (3D) response surface (a) and contour (b) of the decolorization ratio of Congo Red as a function of the independent variables, the $\mathrm{pH}$ of the reaction and the dosage of ferrous sulfate. At low doses of ferrous sulfate, the decolorization ratio of Congo Red increased rapidly with an increase in $\mathrm{pH}$. However, at high doses of ferrous sulfate, the decolorization ratio of Congo Red increased slowly with an increase in $\mathrm{pH}$. In addition, at lower $\mathrm{pH}$ levels, the decolorization ratio of Congo Red increased significantly with an increase in the dosage of ferrous sulfate. At higher $\mathrm{pH}$ levels, the decolorization ratio of Congo Red increased a small amount with an increase in the dosage of ferrous sulfate. The highest decolorization ratio of Congo Red (96.14\%) could, therefore, be obtained with an optimal pH of 10.00 and dosage of $159.64 \mathrm{mg} / \mathrm{L}$. 


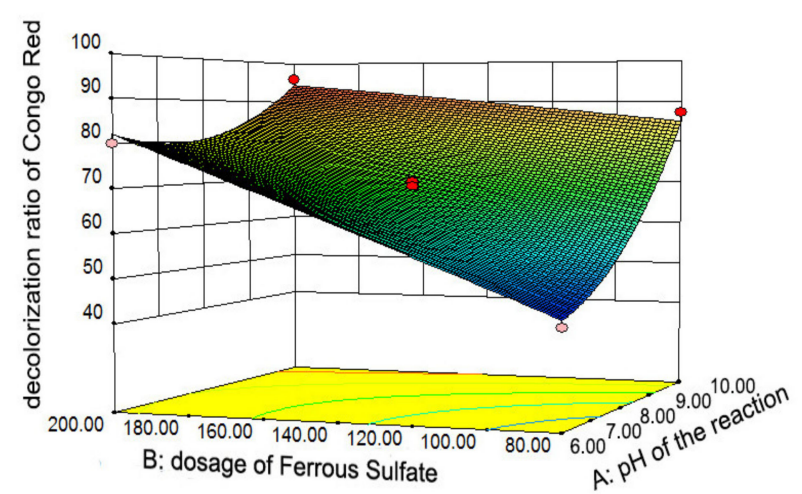

(a)

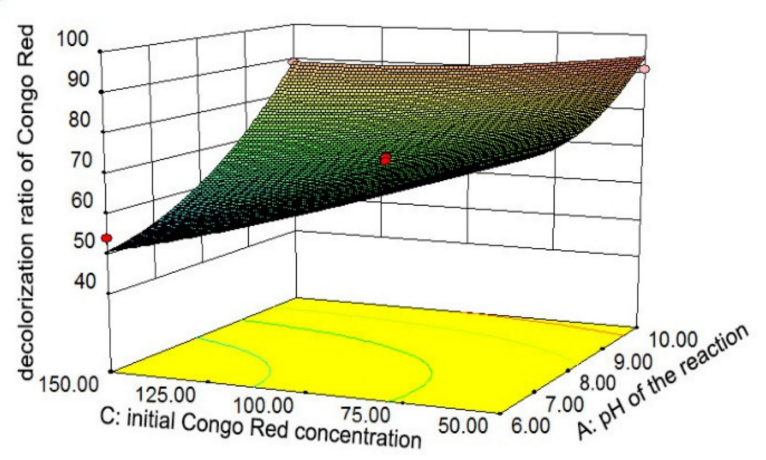

(c)

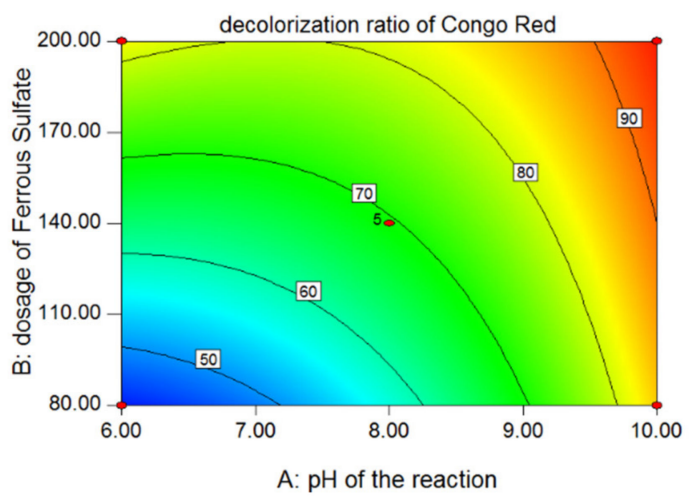

(b)

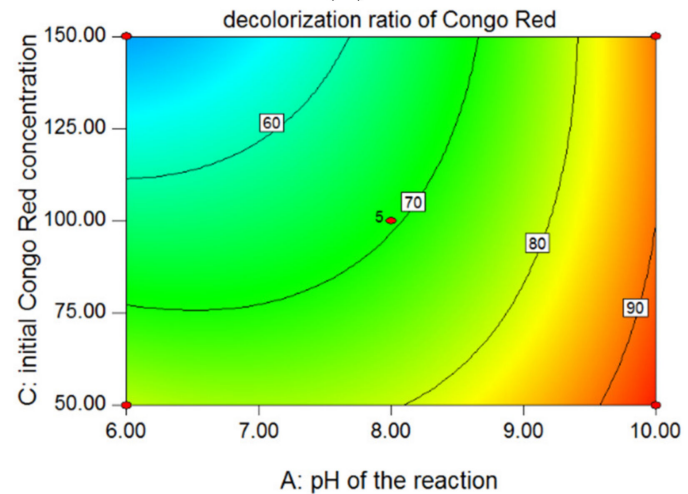

(d)

Figure 1. The three-dimensional (3D) response surface (a) and contour plot (b) for the decolorization ratio of Congo Red under different reaction $\mathrm{pH}$ levels and ferrous sulfate dosages. The 3D response surface (c) and contour plot (d) for the decolorization ratio of Congo Red under different reaction $\mathrm{pH}$ levels and initial Congo Red concentrations.

The effects of the two significant factors, the $\mathrm{pH}$ of the reaction and the initial Congo Red concentration, on the decolorization ratio of Congo Red can be seen in Figure 1c,d. As the initial Congo Red concentrations increased, the decolorization ratio decreased. The decolorization ratio increased with an increase in $\mathrm{pH}$ of the reaction. At a reaction $\mathrm{pH}$ of 10.00 and an initial Congo Red concentration of $50.24 \mathrm{mg} / \mathrm{L}$, a decolorization ratio of Congo Red of $96.14 \%$ was obtained.

The comparison and analyses of the three influencing factors showed that (1) when the $\mathrm{pH}$ of the reaction, the dosage of Ferrous Sulfate, and the initial Congo Red concentration were 10.00, $159.64 \mathrm{mg} / \mathrm{L}$, and $50.24 \mathrm{mg} / \mathrm{L}$, respectively, the decolorization ratio of Congo Red reached its maximum value, and (2) a maximum decolorization ratio of Congo Red of $96.14 \%$ was obtained with simulations using optimal conditions.

\subsection{Box-Behnken Design for Optimizing Factors in the Second Experiment}

RSM with a Box-Behnken design was used to analyze the interaction between basic variables affecting the decolorization removal ratio of Congo Red by aluminum sulfate. These included the $\mathrm{pH}$ of the reaction, initial Congo Red concentration, and dosage of aluminum sulfate. The interaction between two independent variables can be easily understood by using response surface curves and contours. The quadratic polynomial equation constructed by the coding factor was as follows:

$R_{C R}=82.68-21.16 A+34.61 B-9.33 C-2.48 A B+11.50 A C-2.60 B C-20.88 A^{2}-10.13 B^{2}-19.55 C^{2}$,

where $\mathrm{R}_{\mathrm{CR}}$ is the decolorization ratio of Congo Red, and $\mathrm{A}, \mathrm{B}$, and $\mathrm{C}$ represent the $\mathrm{pH}$ of the reaction, the dosage of aluminum sulfate, and the initial Congo Red concentration, respectively. 
Table 2 shows the regression coefficient, standard error, F-value and $p$-value. The model F-value of 12.03 implies that the model was significant. There was only a $0.17 \%$ chance that a value this large could be caused by noise. Table 2 shows that the linear coefficients of the $\mathrm{pH}$ of the reaction $(p<0.0026)$ and dosage of aluminum sulfate $(p<0.0001)$ were vitally significant and had the largest effect on the decolorization ratio of Congo Red. Furthermore, the quadratic coefficients of the $\mathrm{pH}$ of the reaction $(p$ $=0.0139)$ and of the initial Congo Red concentration $(p=0.0186)$ were significant.

Table 2. Regression analysis of least square fitting in the second experiment.

\begin{tabular}{ccccc}
\hline Source & $\begin{array}{c}\text { Regression } \\
\text { Coefficient }\end{array}$ & Standard Error & F-Value & $p$-Value Prob > F \\
\hline Model & - & - & 12.03 & $<0.0017$ \\
A-pH of the reaction & -21.16 & 4.65 & 20.71 & $<0.0026$ \\
B-dosage of aluminum sulfate & 34.16 & 4.65 & 55.40 & $<0.0001$ \\
C-initial Congo Red concentration & -9.33 & 4.65 & 4.02 & $<0.0850$ \\
AB & -2.48 & 6.58 & 0.14 & 0.7178 \\
AC & 11.50 & 6.58 & 3.06 & 0.1238 \\
BC & -2.60 & 6.58 & 0.16 & 0.7044 \\
A & -20.88 & 6.41 & 10.61 & 0.0139 \\
B $^{2}$ & -10.13 & 6.41 & 2.50 & 0.1581 \\
C $^{2}$ & -19.55 & 6.41 & 9.30 & 0.0186 \\
\hline
\end{tabular}

$R^{2}=0.9393$; adjusted $R^{2}=0.8612$; coefficient of variation $=22.34 \%$. " $0.01<p$-value $<0.05$ ", and " $p$-value $>0.1$ " in model terms with "Prob $>F^{\prime \prime}$ were considered to be significant and insignificant, respectively (Su et al., 2016; Shao et al., 2018).

As a function of the independent variables, the $\mathrm{pH}$ of the reaction and the dosage of aluminum sulfate, Figure 2 shows the 3D response surface (a) and contour (b) of the decolorization ratio of Congo Red. With an increase in the reaction $\mathrm{pH}$ level, the decolorization ratio of Congo Red decreased significantly. Meanwhile, with an increase in the aluminum sulfate dosage, the decolorization ratio of Congo Red rapidly increased. The highest decolorization ratio of Congo Red (84.37\%) was obtained with an optimal $\mathrm{pH}$ and aluminum sulfate dosage of 8.26 and $80 \mathrm{mg} / \mathrm{L}$, respectively.

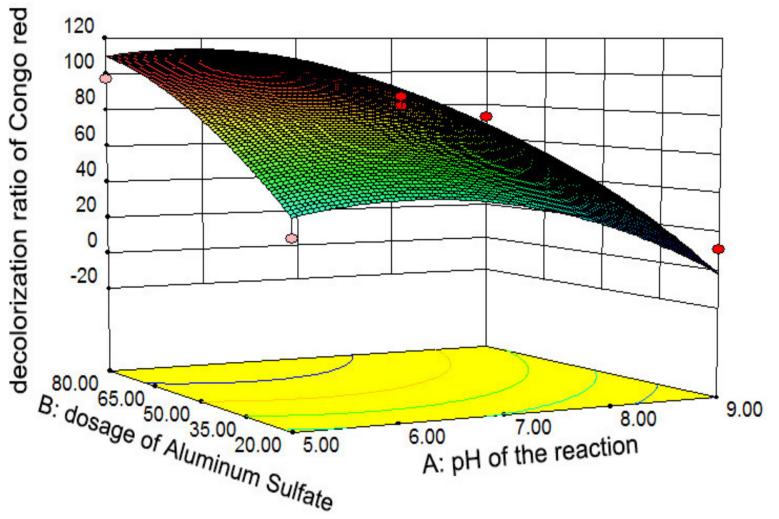

(a)

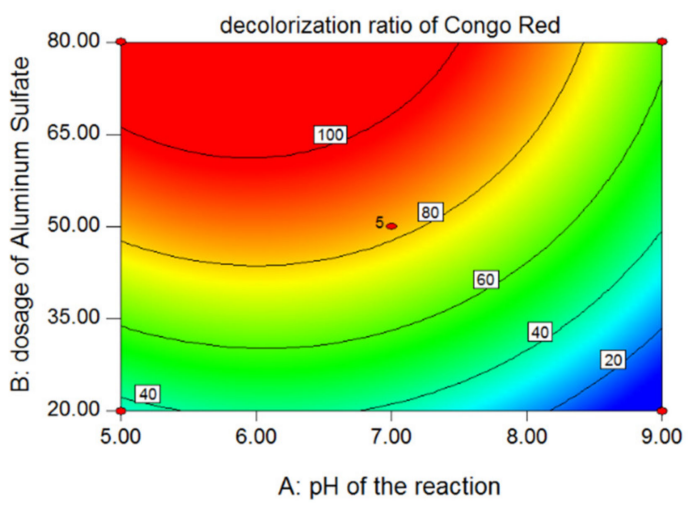

(b)

Figure 2. Cont. 


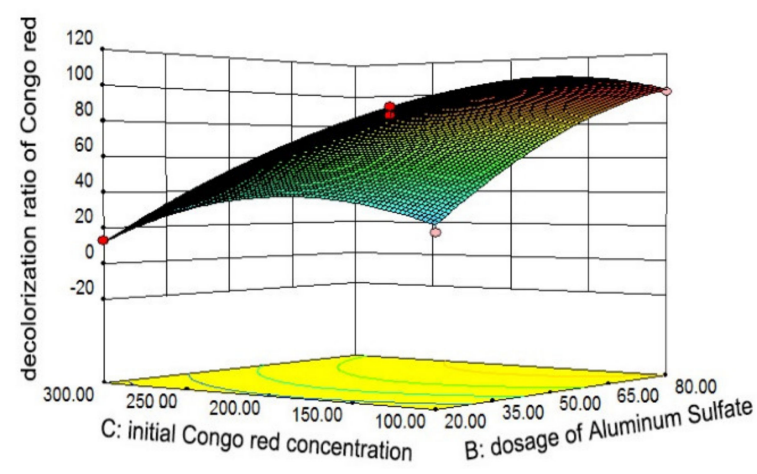

(c)

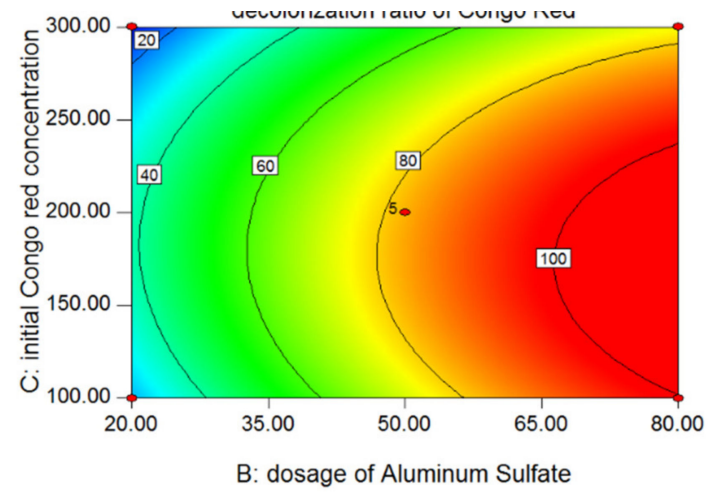

(d)

Figure 2. The 3D response surface (a) and contour plot (b) for the decolorization ratio of Congo Red under different reaction $\mathrm{pH}$ levels and aluminum sulfate dosages. The $3 \mathrm{D}$ response surface (c) and contour plot (d) for the decolorization ratio of Congo Red under different aluminum sulfate dosages and initial Congo Red concentrations.

The effects of the two significant factors, the aluminum sulfate dosage and the initial Congo Red concentration, on the decolorization ratio of Congo Red can be seen in Figure 2c,d. With an increase in the initial concentration of Congo Red, the decolorization ratio firstly increased and then decreased. The inflection point occurred near the initial Congo Red concentration of $175 \mathrm{mg} / \mathrm{L}$. At an aluminum sulfate dosage of $80.00 \mathrm{mg} / \mathrm{L}$ and an initial Congo Red concentration of $187.92 \mathrm{mg} / \mathrm{L}$, a decolorization ratio of Congo Red of $84.37 \%$ was achieved.

The comparison and analyses of the three influencing factors showed that (1) when the $\mathrm{pH}$ of the reaction, the aluminum sulfate dosage, and the initial Congo Red concentration were $8.26,80.00 \mathrm{mg} / \mathrm{L}$, and $187.92 \mathrm{mg} / \mathrm{L}$, respectively, the decolorization ratio of Congo Red reached its maximum value, and (2) under the optimal model conditions, a maximum decolorization ratio of Congo Red of $84.37 \%$ was obtained.

\subsection{Box-Behnken Design for Optimizing Factors in the Third Experiment}

RSM with a Box-Behnken design was used to analyze the interaction between basic variables affecting the decolorization removal ratio of Congo Red by polymeric iron sulfate. These included $\mathrm{pH}$ of the reaction, initial Congo Red concentration, and dosage of polymeric iron sulfate. The interaction between two independent variables can be easily understood by using response surface curves and contours. The quadratic polynomial equation constructed by the coding factor was as follows:

$$
R_{C R}=80.16-5.89 A+29.63 B-6.06 C+2.17 A B-1.50 A C+1.08 B C-5.000 \times 10^{-3} \mathrm{~A}^{2}-14.88 B^{2}+1.85 C^{2},
$$

where $\mathrm{R}_{\mathrm{CR}}$ is the decolorization ratio of Congo Red, and $\mathrm{A}, \mathrm{B}$, and $\mathrm{C}$ represent the $\mathrm{pH}$ of the reaction, the polymeric iron sulfate dosage, and the initial Congo Red concentration, respectively.

Table 3 shows the regression coefficient, standard error, F-value, and $p$-value. The model F-value of 21.85 implies that the model was significant. There was only a $0.03 \%$ chance that a value this large could be caused by noise. Table 3 shows that the linear coefficient $(p<0.0001)$ of the polymeric iron sulfate dosage was vitally significant and had the largest effect on the decolorization ratio of Congo Red. Furthermore, the linear coefficient of the $\mathrm{pH}$ of the reaction $(p=0.0396)$, the linear coefficient of initial Congo Red concentration $(p=0.0355)$, and the quadratic coefficient of dosage of polymeric iron sulfate $(p=0.0024)$ were significant. 
Table 3. Regression analysis of least square fitting in the third experiment.

\begin{tabular}{ccccc}
\hline Source & $\begin{array}{c}\text { Regression } \\
\text { Coefficient }\end{array}$ & Standard Error & F-Value & $p$-Value Prob $>$ F \\
\hline Model & - & - & 21.85 & 0.0003 \\
A-pH of the reaction & -5.89 & 2.33 & 6.37 & 0.0396 \\
B-dosage of polymeric iron sulfate & 29.63 & 2.33 & 161.19 & $<0.0001$ \\
C-initial Congo Red concentration & -6.06 & 2.33 & 6.75 & 0.0355 \\
AB & 2.17 & 3.30 & 0.43 & 0.5309 \\
AC & -1.50 & 3.30 & 0.21 & 0.6632 \\
BC & 1.08 & 3.30 & 0.11 & 0.7541 \\
A $^{2}$ & $-5.000 \times$ & 3.22 & $2.417 \times$ & 0.9988 \\
$\mathrm{~B}^{2}$ & $10^{-3}$ & 3.22 & 21.40 & 0.0024 \\
$\mathrm{C}^{2}$ & -14.88 & 3.22 & 0.33 & 0.5842 \\
\hline
\end{tabular}

$R^{2}=0.9656$; adjusted $R^{2}=0.9214$; coefficient of variation $=8.92 \%$. " $0.01<p$-value $<0.05$ ", and " $p$-value $>0.1$ " in model terms with "Prob $>F$ " were considered to be significant and insignificant, respectively (Su et al., 2016; Shao et al., 2018).

As a function of the independent variables, the $\mathrm{pH}$ of the reaction and polymeric iron sulfate dosage, Figure 3 shows the 3D response surface (a) and contour (b) of the decolorization ratio of Congo Red. With an increase in the reaction $\mathrm{pH}$ level, the decolorization ratio of Congo Red showed a decrease. On the other hand, the decolorization ratio of Congo Red increased rapidly with an increase in polymeric iron sulfate dosage. The highest decolorization ratio of Congo Red (98.28\%) was obtained at an optimal $\mathrm{pH}$ of 6.35 and polymeric iron sulfate dosage of $141.66 \mathrm{mg} / \mathrm{L}$.

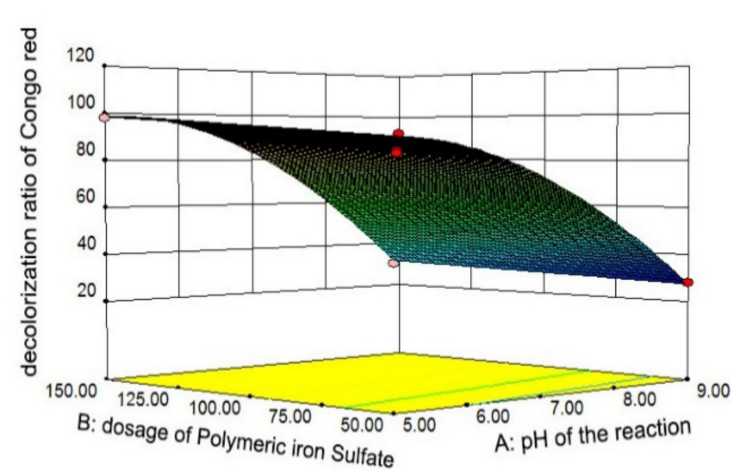

(a)

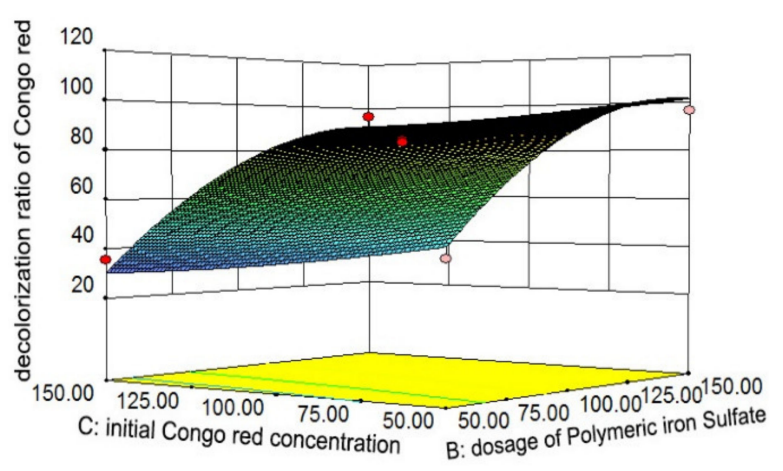

(c)

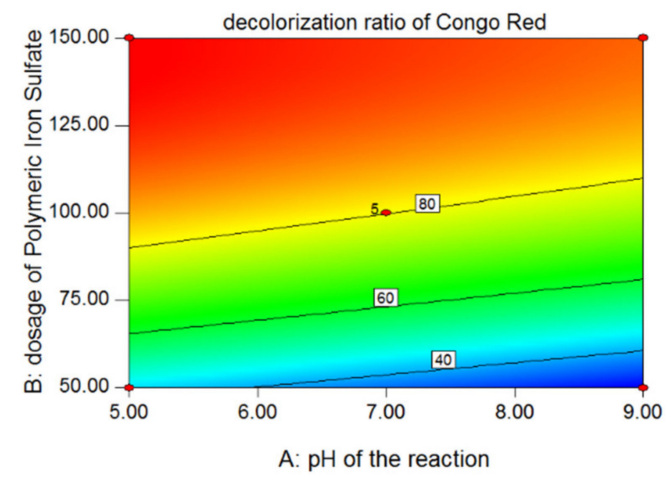

(b)

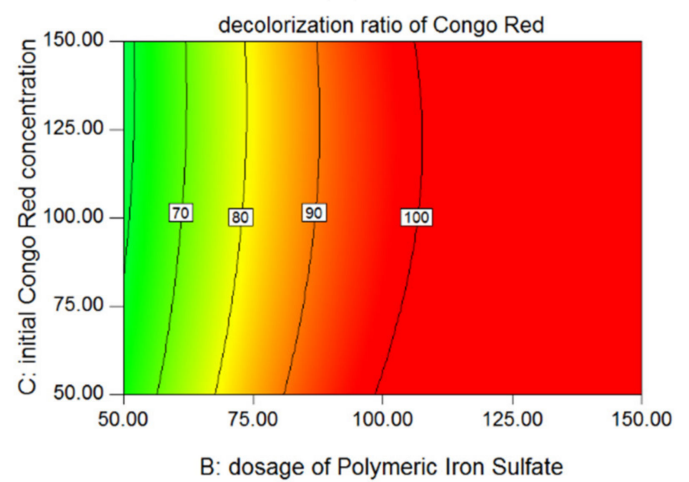

(d)

Figure 3. The 3D response surface (a) and contour plot (b) for the decolorization ratio of Congo Red under different reaction $\mathrm{pH}$ levels and polymeric iron sulfate dosages. The $3 \mathrm{D}$ response surface (c) and contour plot (d) for the decolorization ratio of Congo Red under different polymeric iron sulfate dosages and the initial Congo Red concentrations. 
The effects of the two significant factors, the polymeric iron sulfate dosage and initial Congo Red concentrations, on the decolorization ratio of Congo Red can be seen in Figure 3c,d. With an increase in initial Congo Red concentration, the decolorization ratio decreased. The decolorization ratio of Congo Red also increased rapidly with an increase in the polymeric iron sulfate dosage. At a polymeric iron sulfate dosage of $141.66 \mathrm{mg} / \mathrm{L}$ and initial Congo Red concentration of $77.82 \mathrm{mg} / \mathrm{L}$, a decolorization ratio of Congo Red of $98.28 \%$ was achieved.

The comparison and analyses of the three influencing factors showed that (1) when the $\mathrm{pH}$ of the reaction, the polymeric iron sulfate dosage, and the initial Congo Red concentration were 6.35, $141.66 \mathrm{mg} / \mathrm{L}$, and $77.82 \mathrm{mg} / \mathrm{L}$, respectively, the decolorization ratio of Congo Red reached its maximum value, and (2) under optimal model conditions, a maximum decolorization ratio of Congo Red of $98.28 \%$ was achieved.

\subsection{Characteristics of Microbial Community Structure}

\subsubsection{Bacterial Community Structures}

As shown in Figure 4, after three types of ECPPs were implemented, in comparison to raw wastewater, the microbial community structure of industrial park PDW did not change much, but the relative abundance was slightly different. Proteobacteria, Tenericutes, and Epsilonbacteraeota were the three dominant phyla present. The microbial community structure of L0, L1, L2, L3, and the oxidation ditch (Figure A1, Appendix A) was nearly the same. At the phylum level, the dominant bacteria included Proteobacteria, Firmicutes, and Bacteroidetes. This was also consistent with Zhu et al. (2018) [16], where Proteobacteria, Firmicutes, and Bacteroidetes were the dominant functional microorganisms found after the treatment of PDW. These results demonstrate that ECPPs had no adverse effect on biological treatment.

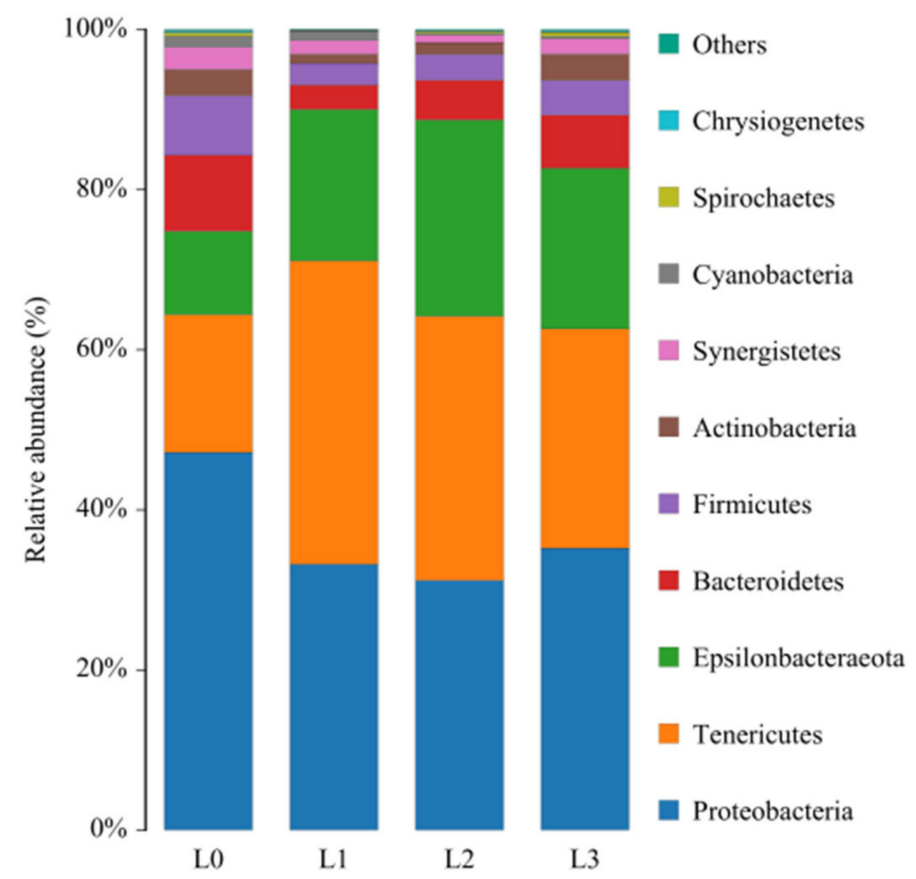

Figure 4. Microbial community structure in different samples at the phylum level. L0 is raw wastewater; L1 is the enhanced coagulation pretreatment process (ECPP) with ferrous sulfate; L2 is the ECPP with aluminum sulfate; L3 is the ECPP with polymeric iron sulfate. The horizontal ordinate is the name of the sample, and the longitudinal coordinate is the relative abundance percentage. 


\subsubsection{Heat Map}

A heat map is a graphical display in which color gradients represent the values in the data matrix and cluster according to the abundance similarity of species or samples. Colors represent the species abundance in heat map clustering [17]. Vertical clustering represents the similarity in abundances of different species in the samples. The closer the distance between two species is, the shorter the branch length is, indicating that the abundance of these two species is more similar between samples. Horizontal clustering represents the similarity of species abundances of different samples. Just like vertical clustering, the closer the distance between two samples is, the shorter the branch length is, indicating that the abundance of species of these two samples is more similar. The color gradient from blue to red indicates the relative abundance from low to high [18].

It can be seen in Figure 5 that the relative abundance value of the microbial community in L0 was the highest, followed by L3. The upper clustering tree indicates that the bacteria in L0 and L3, as well as L1 and L2, were similar. Therefore, ECPPs with polymeric iron sulfate had the lowest effect on the microbial communities in the PDW from the industrial park.

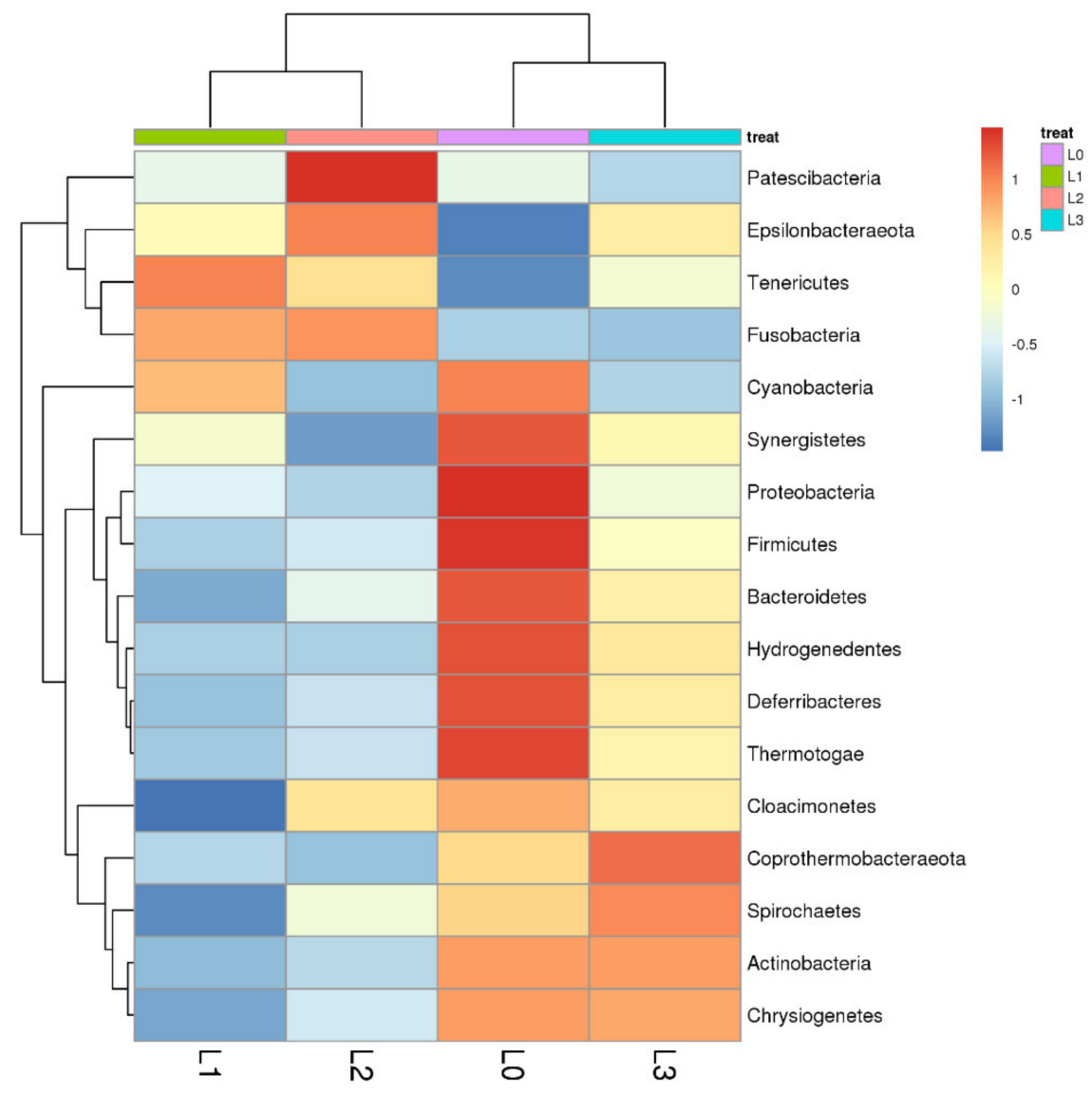

Figure 5. Heat map of different samples at the phylum level. The horizontal clustering is sample information, and the vertical clustering is species information. The left clustering tree is species clustering, the upper clustering tree is sample clustering, and the middle one is the heat map. L0 is raw wastewater, L1 is the ECPP with ferrous sulfate, L2 is the ECPP with aluminum sulfate, and L3 is the ECPP with polymeric iron sulfate.

\section{Conclusions}

In the simulated wastewater examples, using Congo Red as the target pollutant of azo dye, when ferrous sulfate was used as decolorizing agent and the initial concentration of Congo Red was $50.24 \mathrm{mg} / \mathrm{L}$, the reaction $\mathrm{pH}$ value was 10.00 , the ferrous sulfate dosage was $159.64 \mathrm{mg} / \mathrm{L}$, and the maximum decolorizing ratio of Congo Red optimized by RSM was $96.14 \%$. When aluminum sulfate was 
used as a decolorizing agent and the initial concentration of Congo Red was $187.92 \mathrm{mg} / \mathrm{L}$, the reaction $\mathrm{pH}$ value was 8.26 , the aluminum sulfate dosage was $80 \mathrm{mg} / \mathrm{L}$, and the maximum decolorization ratio of Congo Red optimized by RSM was $84.37 \%$. When the initial concentration of Congo Red was $77.82 \mathrm{mg} / \mathrm{L}$, the reaction $\mathrm{pH}$ was 6.35 , the polymeric iron sulfate dosage of was $141.66 \mathrm{mg} / \mathrm{L}$, and the maximum decolorization ratio of Congo Red optimized by RSM was $98.28 \%$. It can, therefore, be concluded that, based on the initial concentration and $\mathrm{pH}$ of Congo Red, different decolorants can be selected for decolorization reactions.

In addition, we found that the microbial community of PDW from the industrial park after three different ECPP treatments was similar to the raw wastewater and oxidation ditch wastewater from the treatment. Proteobacteria, Firmicutes, and Bacteroidetes were the dominant bacteria at the phylum level, meaning that subsequent biological treatment can occur. It was also found that the pretreatment of PDW from the industrial park using polymeric iron sulfate had the smallest effect on the microbial community structure. These results provide a reference for an established link between the physicochemical and biochemical treatment of PDW.

Author Contributions: Conceptualization, X.H.L. and Y.Y.H.; methodology, C.L.; software, C.L.; validation, X.H.L.; formal analysis, X.H.L. and C.L.; data curation, C.L.; writing—original draft preparation, X.H.L. and C.L.; writing-review and editing, X.H.L. and Y.Y.H.; supervision, Y.Y.H.

Funding: This research was funded by the National Natural Science Foundation of China (NO. 21477039, NO. U1401235).

Acknowledgments: The authors wish to thank the anonymous reviewers for their helpful comments.

Conflicts of Interest: The authors declare no conflict of interest.

\section{Appendix A}

Table A1. Seventeen experiments were designed using Design-Expert (version 8.06) software design.

\begin{tabular}{ccccc}
\hline Std & $\begin{array}{c}\text { A: } \mathbf{p H} \text { of the } \\
\text { Reaction }\end{array}$ & $\begin{array}{c}\text { B: Dosage of } \\
\text { Ferrous Sulfate } \\
\mathbf{( m g / L )}\end{array}$ & $\begin{array}{c}\text { C: Initial Congo } \\
\text { Red Concentration } \\
(\mathbf{m g} / \mathbf{L})\end{array}$ & $\begin{array}{c}\text { Decolorization Ratio } \\
\text { of Congo Red } \\
\mathbf{( \% )}\end{array}$ \\
\hline 1 & 6.00 & 80.00 & 100.00 & 42.2 \\
2 & 10.00 & 80.00 & 100.00 & 87.2 \\
3 & 6.00 & 200.00 & 100.00 & 80.0 \\
4 & 10.00 & 200.00 & 100.00 & 95.9 \\
5 & 6.00 & 140.00 & 50.00 & 79.5 \\
6 & 10.00 & 140.00 & 50.00 & 91.0 \\
7 & 6.00 & 140.00 & 150.00 & 54.1 \\
8 & 10.00 & 140.00 & 150.00 & 89.0 \\
9 & 8.00 & 80.00 & 50.00 & 67.5 \\
10 & 8.00 & 200.00 & 50.00 & 94.3 \\
11 & 8.00 & 80.00 & 150.00 & 50.0 \\
12 & 8.00 & 200.00 & 150.00 & 72.2 \\
13 & 8.00 & 140.00 & 100.00 & 71.0 \\
14 & 8.00 & 140.00 & 100.00 & 70.4 \\
15 & 8.00 & 140.00 & 100.00 & 70.7 \\
16 & 8.00 & 140.00 & 100.00 & 69.6 \\
17 & 8.00 & 140.00 & 100.00 & 65.5 \\
\hline
\end{tabular}


Table A2. Seventeen experiments were designed using Design-Expert (version 8.06) software design.

\begin{tabular}{ccccc}
\hline Std & $\begin{array}{c}\text { A: } \mathbf{p H} \text { of the } \\
\text { Reaction }\end{array}$ & $\begin{array}{c}\text { B: Dosage of } \\
\text { Aluminum Sulfate } \\
(\mathbf{m g} / \mathbf{L})\end{array}$ & $\begin{array}{c}\text { C: Initial Congo } \\
\text { Red Concentration } \\
(\mathbf{m g} / \mathbf{L})\end{array}$ & $\begin{array}{c}\text { Decolorization Ratio } \\
\text { of Congo Red } \\
\mathbf{( \% )}\end{array}$ \\
\hline 1 & 20.00 & 200.00 & 25.6 \\
2 & 5.00 & 20.00 & 200.00 & 11.1 \\
3 & 9.00 & 80.00 & 200.00 & 97.2 \\
4 & 5.00 & 80.00 & 200.00 & 72.8 \\
5 & 9.00 & 50.00 & 100.00 & 98.3 \\
6 & 5.00 & 50.00 & 100.00 & 10.1 \\
7 & 9.00 & 50.00 & 300.00 & 51.4 \\
8 & 5.00 & 50.00 & 300.00 & 9.2 \\
9 & 9.00 & 20.00 & 100.00 & 21.2 \\
10 & 7.00 & 80.00 & 100.00 & 98.2 \\
11 & 7.00 & 20.00 & 300.00 & 13.0 \\
12 & 7.00 & 80.00 & 300.00 & 79.6 \\
13 & 7.00 & 50.00 & 200.00 & 84.2 \\
14 & 7.00 & 50.00 & 200.00 & 83.7 \\
15 & 7.00 & 50.00 & 200.00 & 75.5 \\
16 & 7.00 & 50.00 & 200.00 & 88.9 \\
17 & 7.00 & 50.00 & 200.00 & 81.1 \\
\hline
\end{tabular}

Table A3. Seventeen experiments were designed using Design-Expert (version 8.06) software design.

\begin{tabular}{ccccc}
\hline Std & $\begin{array}{c}\text { A: } \mathbf{p H} \text { of the } \\
\text { Reaction }\end{array}$ & $\begin{array}{c}\text { B: Dosage of Polymeric } \\
\text { Iron Sulfate } \\
(\mathbf{m g} / \mathbf{L})\end{array}$ & $\begin{array}{c}\text { C: Initial Congo red } \\
\text { Concentration } \\
(\mathbf{m g} / \mathbf{L})\end{array}$ & $\begin{array}{c}\text { Decolorization Ratio } \\
\text { of Congo Red } \mathbf{\%})\end{array}$ \\
\hline 1 & 5.00 & 50.00 & 100.00 & 42.5 \\
2 & 9.00 & 50.00 & 100.00 & 28.1 \\
3 & 5.00 & 150.00 & 100.00 & 98.1 \\
4 & 9.00 & 150.00 & 100.00 & 92.4 \\
5 & 5.00 & 100.00 & 50.00 & 98.1 \\
6 & 9.00 & 100.00 & 50.00 & 87.6 \\
7 & 5.00 & 100.00 & 150.00 & 79.4 \\
8 & 9.00 & 100.00 & 150.00 & 62.9 \\
9 & 7.00 & 50.00 & 50.00 & 40.2 \\
10 & 7.00 & 150.00 & 50.00 & 96.6 \\
11 & 7.00 & 50.00 & 150.00 & 35.5 \\
12 & 7.00 & 150.00 & 150.00 & 96.2 \\
13 & 7.00 & 100.00 & 100.00 & 71.2 \\
14 & 7.00 & 100.00 & 100.00 & 83.2 \\
15 & 7.00 & 100.00 & 100.00 & 79.2 \\
16 & 7.00 & 100.00 & 100.00 & 84.1 \\
17 & 7.00 & 100.00 & 100.00 & 83.1 \\
\hline
\end{tabular}

Table A4. The actual characteristics of the wastewater.

\begin{tabular}{ccccccc}
\hline pH & $\begin{array}{c}\text { Chemical } \\
\text { Oxygen Demand } \\
(\mathbf{m g} / \mathrm{L})\end{array}$ & $\begin{array}{c}\mathrm{PO}_{4}{ }^{3-}-\mathrm{P} \\
(\mathbf{m g} / \mathrm{L})\end{array}$ & $\begin{array}{c}\text { Total } \\
\text { Phosphorus } \\
(\mathbf{m g} / \mathrm{L})\end{array}$ & $\begin{array}{c}\text { Suspended solids } \\
(\mathbf{m g} / \mathrm{L})\end{array}$ & $\mathrm{SO}_{4}{ }^{2-}(\mathbf{m g} / \mathrm{L})$ & $\begin{array}{c}\text { Color } \\
(\mathbf{m g} \mathbf{P t} / \mathrm{L})\end{array}$ \\
\hline 8.68 & 1550 & 9.3 & 53.4 & 3150 & 3800 & 1900 \\
\hline
\end{tabular}

Table A5. List of abbreviations.

\begin{tabular}{cc}
\hline Abbreviation & Full Name \\
\hline PDW & Printing and dyeing wastewater \\
RSM & Response surface methodology \\
ECPPs & Enhanced coagulation pretreatment processes \\
\hline
\end{tabular}




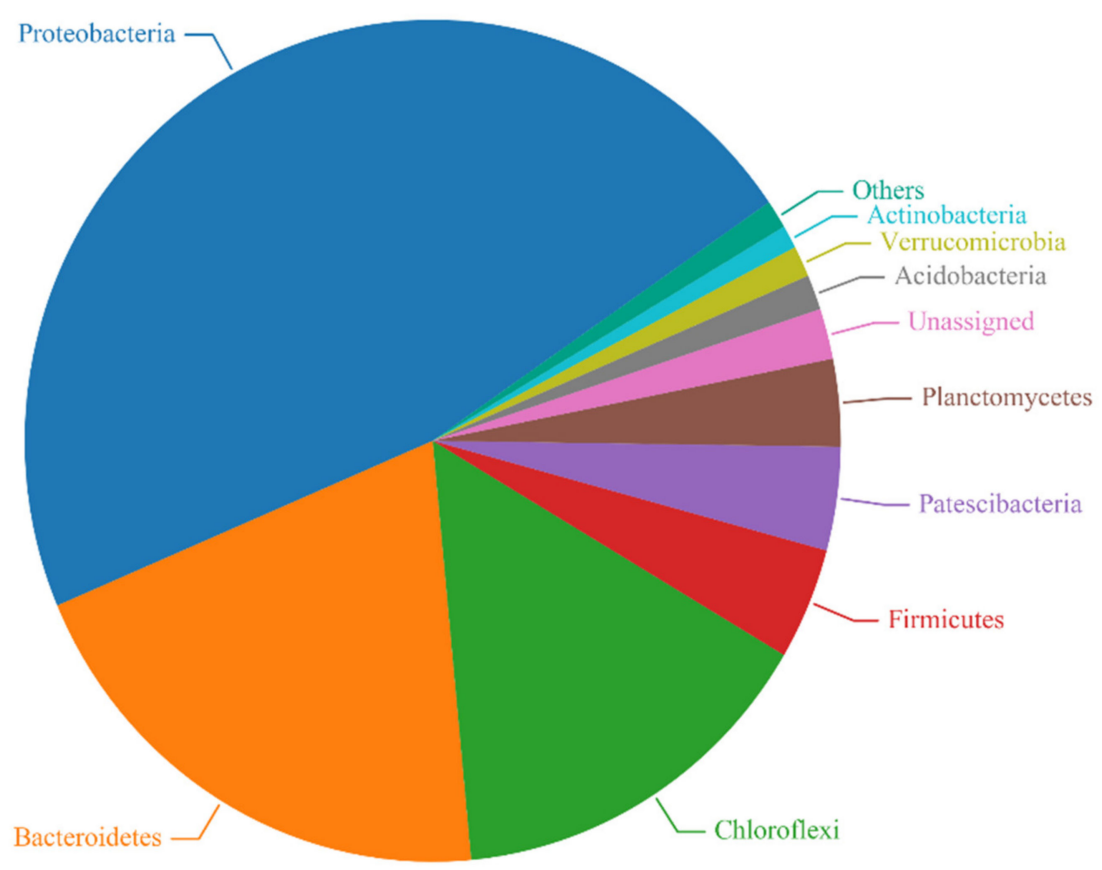

Figure A1. The microbial community structure of the oxidation ditch.

\section{References}

1. Li, R.; Liu, X.J.; Wang, H.; Wu, Y.; Chan, K.C.; Lu, Z.P. Flexible glassy grid structure for rapid degradation of azo dye. Mater. Des. 2018, 155, 346-351. [CrossRef]

2. Hussain, T.; Wahab, A. A critical review of the current water conservation practices in textile wet processing. J. Clean. Prod. 2018, 198, 806-819. [CrossRef]

3. Nguyen, T.A.; Juang, R.-S. Treatment of waters and wastewaters containing sulfur dyes: A review. Chem. Eng. J. 2013, 219, 109-117.

4. Katheresan, V.; Kansedo, J.; Lau, S.Y. Efficiency of various recent wastewater dye removal methods: A review. J. Environ. Chem. Eng. 2018, 6, 4676-4697. [CrossRef]

5. Chang, J.S.; Lin, C.Y. Decolorization kinetics of recombinant Escherichia colistrain harboring azo dye decolorization determinants for Rhodococcus sp. Biotechnol. Lett. 2001, 23, 631-636. [CrossRef]

6. Leechart, P.; Nakbanpote, W.; Thiravetyan, P. Application of 'waste' wood-shaving bottom ash for adsorption of azo reactive dye. J. Environ. Manag. 2009, 90, 912-920. [CrossRef]

7. Xu, H.; Heinze, T.M.; Chen, S.; Cerniglia, C.E.; Chen, H. Anaerobic metabolism of 1-amino-2-naphthol-based azo dyes (Sudan dyes) by human intestinal microflora. Appl. Environ. Microbiol. 2007, 73, 7759-7762. [CrossRef] [PubMed]

8. Singh, R.P.; Singh, P.K.; Singh, R.L. Bacterial decolorization of textile azo dye Acid Orange by Staphylococcus hominis RMLRT03. Toxicol. Int. 2014, 21, 160-166. [CrossRef] [PubMed]

9. Bilińska, L.; Blus, K.; Gmurek, M.; Ledakowicz, S. Coupling of electrocoagulation and ozone treatment for textile wastewater reuse. Chem. Eng. J. 2019, 358, 992-1001. [CrossRef]

10. Su, J.F.; Shao, S.C.; Huang, T.L.; Ma, F.; Zhang, K.; Wen, G.; Zheng, S.C. Isolation, identification, and algicidal activity of aerobic denitrifying bacterium R11 and its affect on Microcystis aeruginosa. Water Sci. Technol. 2016, 73, 2600-2607. [CrossRef] [PubMed]

11. Zhao, S.; Gao, B.; Yue, Q.; Wang, Y. Effect of Enteromorpha polysaccharides on coagulation performance and kinetics for dye removal. Colloids Surf. A Physicochem. Eng. Asp. 2014, 456, 253-260. [CrossRef]

12. Dotto, J.; Fagundes-Klena, M.R.; Veita, M.T.; Palacio, S.M.; Bergamasco, R. Performance of different coagulants in the coagulation/flocculation process of textile wastewater. J. Clean. Prod. 2019, 208, 656-665. [CrossRef]

13. Huang, X.; Bo, X.; Zhao, Y.; Gao, B.; Wang, Y.; Sun, S.; Yue, Q.; Li, Q. Effects of compound bioflocculant on coagulation performance and floc properties for dye removal. Bioresour. Technol. 2014, 165, 116-121. [CrossRef] [PubMed] 
14. Xie, J.; Wang, D.; John van, L.; Zhao, Y.; Xing, L.; Chow, C.W.K. pH modeling for maximum dissolved organic matter removal by enhanced coagulation. J. Environ. Sci. 2012, 24, 276-283. [CrossRef]

15. Lee, K.E.; Morad, N.; Teng, T.T.; Poh, B.T. Development, characterization and the application of hybrid materials in coagulation/flocculation of wastewater: A review. Chem. Eng. J. 2012, 203, 370-386. [CrossRef]

16. Zhu, Y.; Xu, J.; Cao, X.; Cheng, Y. Characterization of functional microbial communities involved in different transformation stages in a full-scale printing and dyeing wastewater treatment plant. Biochem. Eng. J. 2018, 137, 162-171. [CrossRef]

17. Shao, S.C.; Hu, Y.Y.; Cheng, J.H.; Chen, Y.C. Action of oxytetracycline (OTC) degrading bacterium and its application in Moving Bed Biofilm Reactor (MBBR) for aquaculture wastewater pre-treatment. Ecotoxicol. Environ. Saf. 2019, 171, 833-842. [PubMed]

18. Wilkinson, L.; Friendly, M. The history of the cluster Heat map. Am. Stat. 2009, 63, 179-184. [CrossRef]

(C) 2019 by the authors. Licensee MDPI, Basel, Switzerland. This article is an open access article distributed under the terms and conditions of the Creative Commons Attribution (CC BY) license (http://creativecommons.org/licenses/by/4.0/). 